\title{
EPATITE CRONICA B ASSOCIATA AD INFEZIONE DA HCV
}

\author{
Leone R.A., Minchella P., Nisticò S., Potente G.I., \\ Caruso D., Camerino M., Gagliardi B., Nicolazzo A., \\ Luciano A.
}

U.O. Microbiologia e Virologia, Azienda Sanitaria N. 6, Via Perugini I, 88046 Lamezia Terme (CZ)

\section{Introduzione.}

La coinfezione $\mathrm{HBV} / \mathrm{HCV}$, soprattutto nei soggetti ad alto rischio in aree geografiche endemiche, è un'evenienza non rara, probabilmente sottostimata. La duplice infezione ha una notevole rilevanza clinica, sia per le implicazioni terapeutiche, sia per l'aumentato rischio di evoluzione in cirrosi ed epatocarcinoma. I dati riguardanti i pazienti HBsAg/antiHCV positivi (3-5\% dei soggetti italiani con epatite cronica virale, secondo un recente studio) sono ancora pochi, soprattutto per quanto riguarda l'aspetto clinico virologico. Scopo del lavoro è valutare la percentuale di positività anti-HCV e la viremia in un gruppo di pazienti con epatite cronica B (soggetti HBsAg/anti-HCV positivi), afferenti alla nostra Unità Operativa per indagini diagnostiche

\section{Metodi.}

Sono stati utilizzati i seguenti metodi:

A) markers sierologici: metodo Meia (Axsym, Abbott); B) test di conferma anti-HCV: metodo immunoenzima-tico su striscia (INNO-LIA HCV Score, Innogenetics); C) HBVDNA: PCR quantitativa (Cobas Amplicor HBV Monitor, Roche Diagnostics); D) HCV-RNA: PCR qualitativa e quantitativa (Cobas Amplicor HCV e Cobas Amplicor HCV Monitor, Roche Diagnostics);

\section{Risultati.}

Abbiamo considerato un gruppo di 310 pazienti con Epatite cronica B, n. 201 maschi e n. 109 femmine. In 13 (9 maschi e 4 femmine, con età media di circa 44 anni) dei 310 pazienti HBsAg positivi è stata riscontrata reattività per anti-HCV, confermata con il test INNO-LIA HCV; la percentuale di coinfezione è risultata del $4,2 \%$, in accordo con quanto rilevato in altri studi. Per quanto riguarda la viremia $\mathrm{HBV}$ ed HCV nei 13 pazienti è risultato un profilo virologico eterogeneo: a) tra i 7 soggetti HBV-DNA positivi n. 4 presentavano HCV-RNA positivo e n. $3 \mathrm{HCV}$-RNA negativo; b) tra i 6 soggetti HBV-DNA negativi n. 3 erano HCV-RNA positivi e n. 3 negativi.

\section{Conclusioni.}

Nei pazienti studiati non è stato osservato un netto effetto inibitorio di uno dei due virus nei confronti della replicazione dell'altro, come invece riportato in recenti studi. La coinfezione $\mathrm{HBV} / \mathrm{HCV}$ probabilmente non presenta un quadro virologico stabile, ma un profilo dinamico che può evolvere nel tempo: solo un attento monitoraggio della carica virale di $\mathrm{HCV}$ ed HBV può indicare se uno o entrambi i virus abbiano fasi alterne di attiva o soppressa replicazione. E' importante quindi nei pazienti HBsAg/anti-HCV positivi eseguire un follow-up molto accurato, con valutazione ripetuta nel tempo della viremia di entrambi i virus, per adottare il programma terapeutico più efficace. 